\title{
Trichuris trichiura in the mummified remains of southern Siberian nomads
}

Vyacheslav Sergeyevich Slavinsky ${ }^{1}$,

Konstantin Vladimirovich Chugunov ${ }^{2}$, Alexander Alekseevich Tsybankov ${ }^{1}$, Sergey Nikolaevich Ivanov ${ }^{3}$, Alisa Vladimirovna Zubova ${ }^{4} \&$ Sergey Mikhailovich Slepchenko ${ }^{3,5, *}$

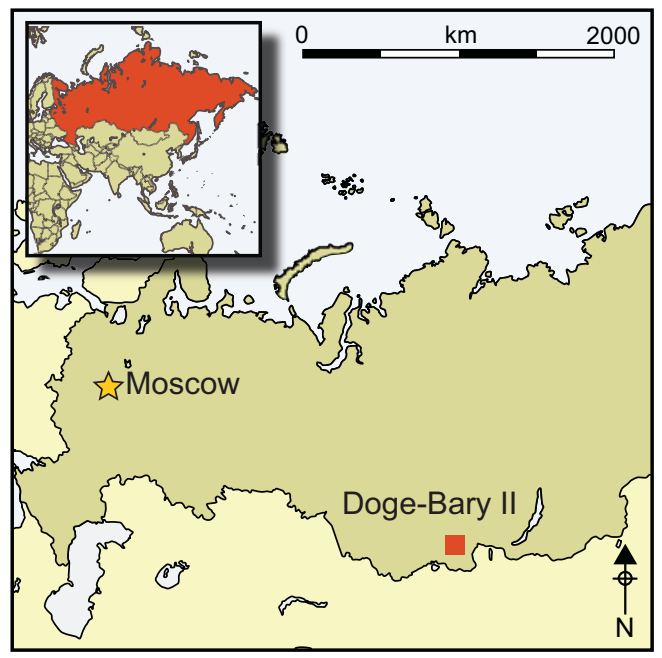

The identification of parasites in ancient human remains can address questions of past health, disease, mobility and mortuary customs. Archaeoparasitological evidence from Russia is, however, almost absent. This study presents the first such evidence in the form of a helminth infection in a mummified individual from the southern Siberian site of Doge-Bary II, the burial ground of a nomadic Iron Age community. Despite the removal of the intestines as part of the mummification procedure, the residual eggs of Trichuris trichiura, a non-indigenous species of whipworm, were detected. This evidence provides the first confirmation of prehistoric contact between southern Siberian nomads and distant agricultural areas, such as China and Central Asia.

Keywords: Siberia, Iron Age, Uyuk-saglynsk, parasitology, Trichuris trichura

\section{Introduction}

Mummies and mummified remains have been found all around the world, and are a crucial source of evidence for the presence of prehistoric parasites (Cockburn et al. 1998;

1 Institute of Archaeology and Ethnography, Siberian Branch of the Russian Academy of Sciences Novosibirsk, Lavrent'ev Avenue 17, Novosibirsk 630090, Russia

2 The State Hermitage Museum, Department of Eastern European and Siberian Archaeology, Palace Square 2, Saint Petersburg 190000, Russia

3 Tyumen Scientific Center, Siberian Branch of the Russian Academy of Sciences, 86 Malygina Street, Tyumen 625003, Russia

4 Peter the Great Museum of Anthropology and Ethnography (The Kunstkamera), University Embankment 3, Saint Petersburg 199034, Russia

5 Ltd Paleopoisk, Demakova street, 23/5, Novosibirsk 630128, Russia

*Author for correspondence (Email: s_slepchenko@list.ru) 
Aufderheide 2003; Reinhard \& Urban 2003; Sianto et al. 2005). Natural mummies are quite rare, as specific environmental conditions are required for their preservation, such as dry climate, an oxygen-free environment, permafrost or salt mines (Fischer 1980; Aspöck et al. 1996; Harter 2003; Kumm et al. 2010; Nezamabadi et al. 2013; Searcey et al. 2013).

There are numerous cases where the intentional mummification of dead human bodies has been demonstrated (Peck 1998). In Russia, such discoveries are mainly located in the Altai Mountains, which have yielded many examples of mummies and mummified remains since the beginning of archaeological excavations in the nineteenth century. The best known are those at the Ak-Alakha III and Verkh-Kalgin II burial mounds on the Ukok plateau (Polosmak 2000; Letyagin et al. 2014). The well-preserved Altai mummies allow detailed reconstruction of the whole process of artificial mummification. The ice that formed in the underground timber chambers shortly after burial contributed to their preservation to the present day (Polosmak 1996, 2000). Although less famous, mummified bodies from the Doge-Bary II burial ground, dated to the fifth to fourth centuries BC, in the Tuva Basin are nonetheless of considerable interest (Chugunov 2007; Zubova 2009). Analysis of the

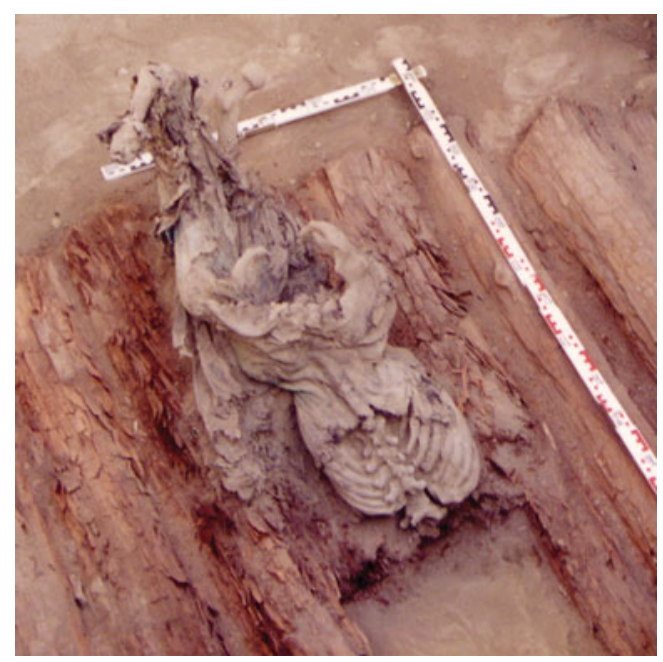

Figure 1. The mummified remains of individual 1 from Doge-Bary II. best-preserved mummified remains, those of a man aged 25-30 years (individual 1; Figure 1) from burial mound 6, allowed the process of artificial mummification to be provisionally reconstructed. Specifically, traces of post-mortem manipulation in the form of a cut at least $0.1 \mathrm{~m}$ long were recorded on the surviving tissues of anterior abdominal wall. The total length of the incision could not be established owing to limited preservation of the remains. The cut was located between the eighth and ninth ribs on the left side of the body, and was probably intended for the removal of internal organs. When the procedure was completed, the incision was sutured in a direction to follow the anatomical arrangement of the ribs. No traces of any artificial abdominal or pelvic filler were found (Zubova 2009).

We performed an archaeoparasitological analysis on the mummified remains of three of the four individuals recovered from burial mound 6 at Doge-Bary II. Unfortunately, the fourth body (individual 4) was not available for analysis and could not be included in this archaeoparasitological study. The initial aims of this research were to investigate which parasite species might be present in this Iron Age population and to trace the routes of Trichuris trichiura penetration into southern Siberia.

Trichuris trichiura whipworm is an infectious agent causing trichuriasis, a helminthiasis (infestation with parasitic worms) typically found in areas with humid, warm, tropical or subtropical climates (Figure 2) (Bundy et al. 1985; Vozianova 2000). The optimum 


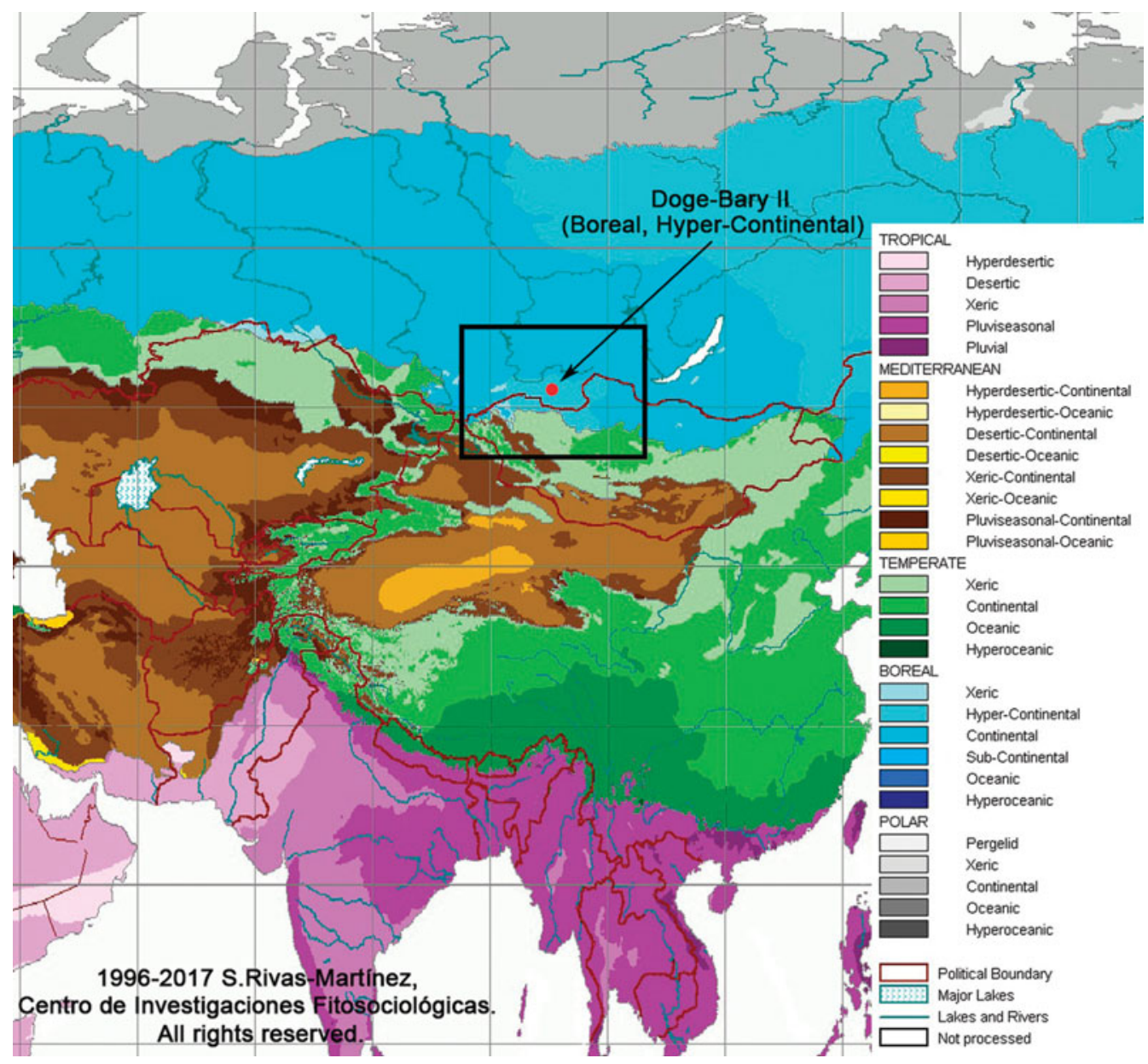

Figure 2. Bioclimatic map of Asia.

conditions for the development and maturation of whipworm eggs are temperatures of $+30^{\circ} \mathrm{C}$ with humidity close to 100 per cent. Helminth eggs are very sensitive to dry conditions, lack of oxygen and low temperatures (Vozianova 2000). Climatic conditions in the Tuva region where Doge-Bary II is located were, therefore, unsuitable for the development of long-term foci of Trichuris trichiura, and the risk of trichuriasis infection was accordingly limited. In fact, this highland area has an extremely dry climate (average annual precipitation of approximately $150-200 \mathrm{~mm}$ ), with a large average temperature range including very low winter temperatures (Gvozdetsky \& Mikhailov 1978).

\section{Archaeological context}

Archaeological excavations at the Doge-Bary II burial mounds were carried out in 19901998 by the Central Asian expedition led by K.V. Chugunov. The burial ground is located at

(C) Antiquity Publications Ltd, 2018 


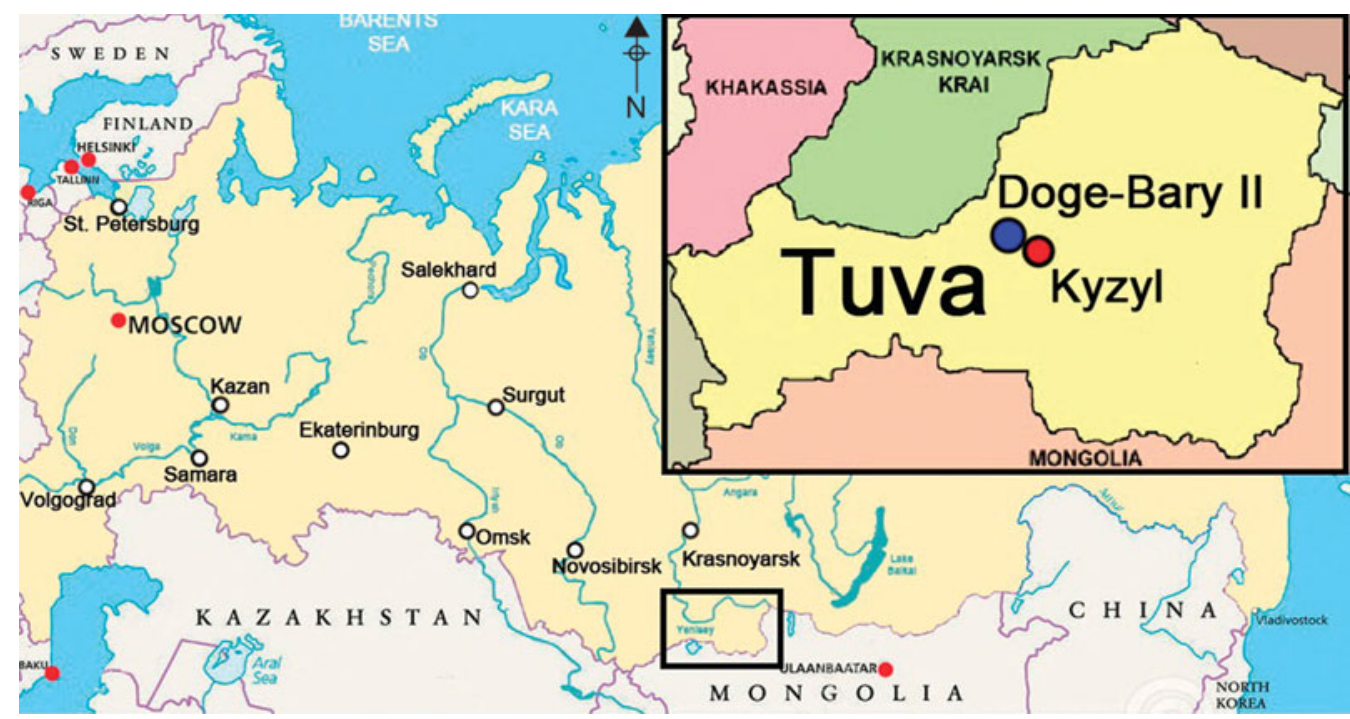

Figure 3. Location of the archaeological site of Doge-Bary II. The site is marked in blue.

the foot of Doge Mountain, on a high terrace on the right bank of the Bi-Khem River (Big Yenisey), close to the town of Kyzyl (Figure 3). The burial ground belongs to the Uyuksaglynsk culture, which is associated with a group of early nomadic societies in Central Asia. Stratigraphy and a large series of radiocarbon determinations, as well as analysis of the archaeological site, have shown it to date to the fifth and fourth centuries BC (Chugunov 2007).

The remains of three mummified individuals were recovered from burial mound 6 . They were interred in a central burial pit that took the form of a rectangular, larch, log-built construction, with overlapping logs giving the appearance of intact walls. One mummified body (individual 1) was found on an overlapping section outside the central burial pit (Figure 4). It appears that robbers broke in through one of the logs, breaking it off, and disturbed the bodies of three adults and dragged individual 1 onto an overlapping section. The burial pit was filled with clay loam through the breach after the grave was robbed. As no traces of the robbers were found in the stratigraphy (except the broken log on entry), it can be inferred that the burial pit was not filled with clay at the time of the robbery. Clay probably penetrated the burial pit following the robbery, thus preserving the wood of the grave chamber and the human burials within.

\section{Materials and methods}

Samples for archaeoparasitological analysis were taken from the pelvis area of three male individuals. Six samples were taken (two from each individual), including mummified tissue fragments for archaeoparasitological analysis and control samples from lower limbs. Following precautionary measures (sterilised gloves, mask and tools), tweezers were used to remove fragments of mummified soft tissue adjacent to the pelvic surface of the sacrum and 


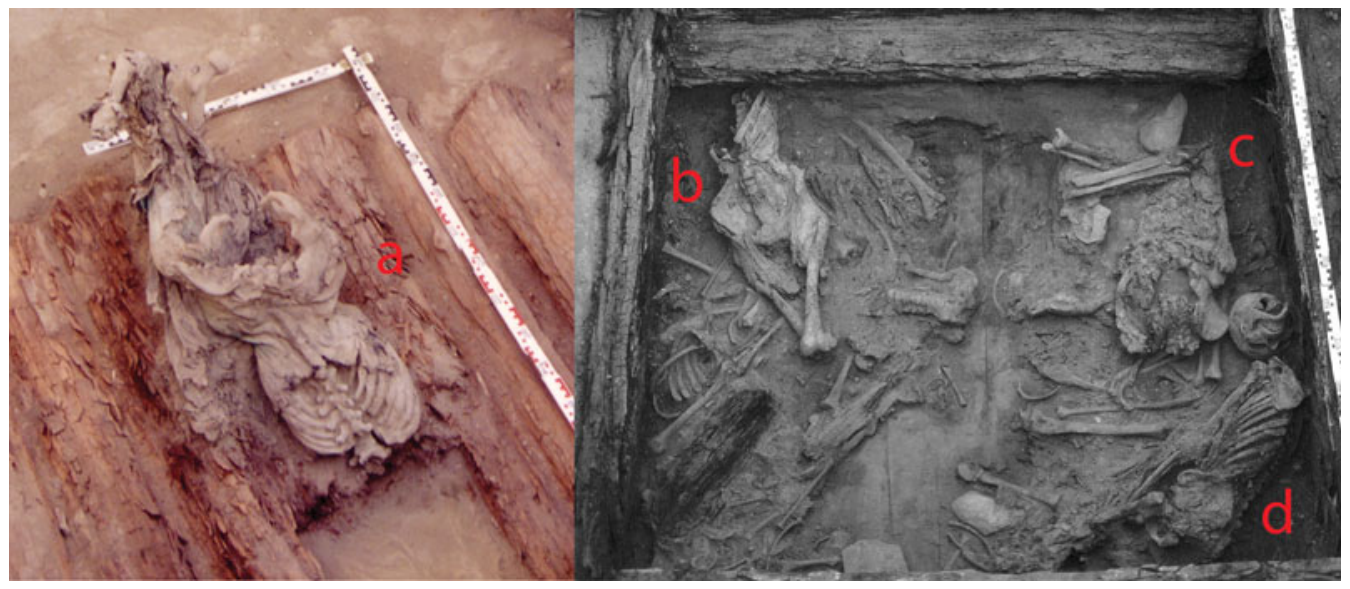

Figure 4. Mummified remains of individuals excavated at Doge-Bary II: a) individual 1; b) individual 2; c) individual 3; d) individual 4 .

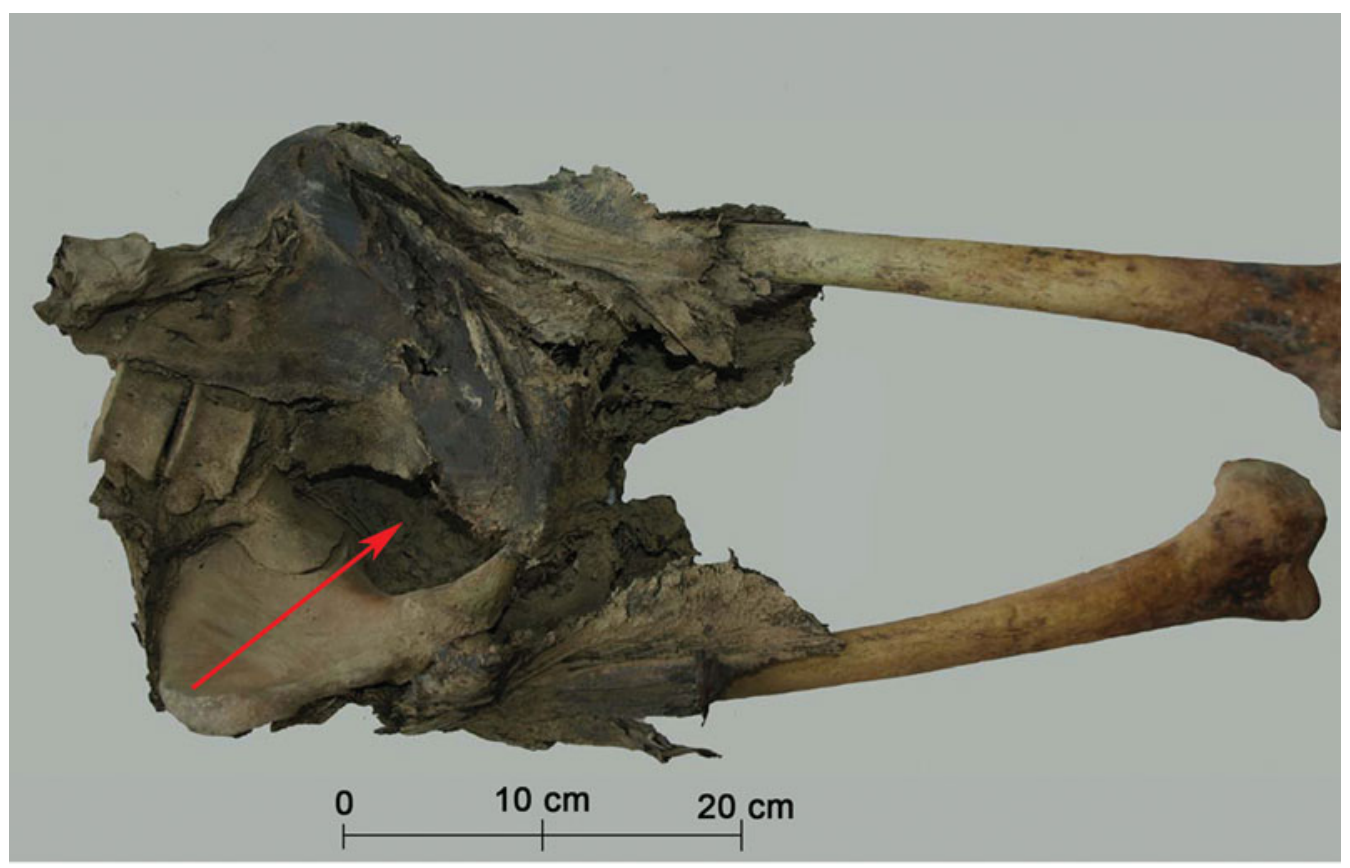

Figure 5. Mummified remains of individual 2; the red arrow indicates sample collection locations.

pelvic diaphragm (Figure 5). Moreover, following the recommended procedure for such cases (Fugassa et al. 2008), we cleaned the pelvic walls with a soft brush; and exfoliated mummified tissue fragments obtained from the cleaning procedure were also used for analysis. Fragments of exfoliated soft tissues from the lower limbs of all individuals were used as control samples in addition to the ones mentioned above.

(C) Antiquity Publications Ltd, 2018 
Preparation of the sediment samples collected from the pelvic region and sacral foramina was as follows (Slepchenko et al. 2016, 2017). A $1 \mathrm{~g}$ sample was ground and placed in a $0.2 \mathrm{~L}$ beaker. A 0.5 per cent trisodium phosphate solution $\left(\mathrm{Na}_{3} \mathrm{PO}_{4}\right)$ was then added (Callen \& Cameron 1960; Araújo

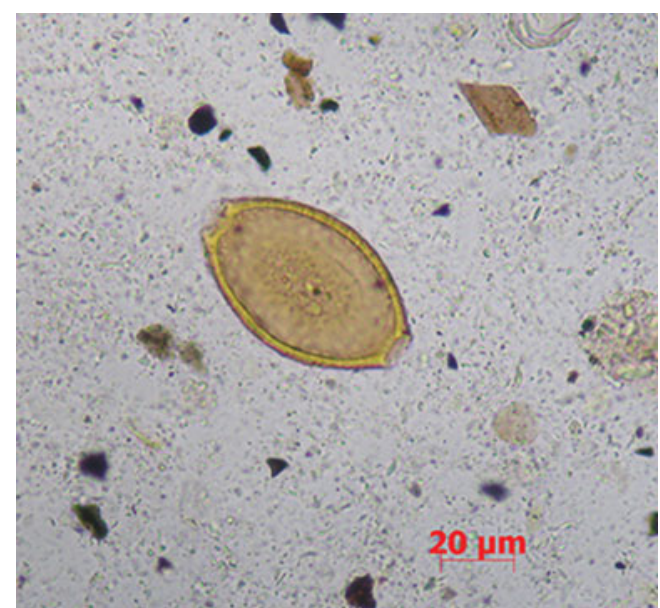

Figure 6. Egg suggestive of Trichuris trichiura found in mummified remains from Doge-Bary II. et al. 1998). The supernatant fluid was suspended three times over the course of one week, with a freshly made solution of $\mathrm{Na}_{3} \mathrm{PO}_{4}$ added each time. The residue was then screened through a $200 \mu \mathrm{m}$ sieve. After screening, a freshly made solution of $\mathrm{Na}_{3} \mathrm{PO}_{4}$ was added, and sample separation was conducted in centrifuge tubes. The residue was concentrated by multiple centrifuge processes for 7 minutes (1500rpm) (Dufour \& Le Bailly 2013). We then added glycerine and thoroughly stirred the residue. The tube was heated in a water bath at $80^{\circ} \mathrm{C}$ for 10 minutes and then centrifuged for 7 minutes (1500rpm). The glycerine and water were then agitated.

These preparative steps resulted in a total of 20 slides for examination, created using standard methods (Reinhard et al. 1986; Araújo et al. 1998). Microscopic examination was conducted using AxioSkop 40 and AmScope MU800 microscopes under $80 \times$ and $400 \times$ magnification. The software program AxioVision 4.6 was used for measurement.

\section{Results}

Two helminth eggs were discovered during analysis of the sample from individual 2 . Morphologically, these eggs were elongated and barrel-shaped, with a thick wall and a double outline. The internal contents and mucoid polar plugs on the poles of the eggs were absent, probably due to taphonomic processes. The size of the first egg was $62.25 \times$ $24.5 \mu \mathrm{m}$, while the second one was $65.21 \times 22.5 \mu \mathrm{m}$ (Figure 6). From these morphological and morphometric characteristics, we identified the eggs to be of the genus Trichuris (Ash \& Orihel 2007). Helminth eggs were not found in the tissue samples from individuals 3 and 4 , nor in the control samples (Table 1).

\section{Discussion}

Archaeoparasitological investigations suggest a high frequency of trichuriasis among ancient populations worldwide, except in territories with cold and dry climates. Trichuris sp. eggs have been found in soil and coprolites dating from the Neolithic period to modern times (Gonçalves et al. 2003; Searcey et al. 2013; Bianucci et al. 2015). The nearest examples of archaeological Trichuris sp. eggs to Doga-Bary II come from sites in China and Central Asia (Wei 1973; Yang et al. 1984; Yeh \& Mitchell 2016; Yeh et al. 2016). The genus Trichuris 
Table 1. Archaeoparasitological results from the Doge-Bary II burial ground, Russia. + positive result; - negative result; $[\mathrm{x}]$ number of eggs found; ${ }^{*}$ samples from individual 4 have not been investigated.

\begin{tabular}{lccc}
\hline Mummy & $\begin{array}{c}\text { Mummified tissue } \\
\text { fragments from pelvis }\end{array}$ & Control sample & Parasites \\
\hline Individual 1 & - & - & \\
Individual 2 & $+[2]$ & - & Trichuris sp. \\
Individual 3 & - & - & \\
Individual 4* & & & \\
\hline
\end{tabular}

includes numerous species of parasitic worms. Some species, such as Trichuris trichiura, Trichuris suis and Trichuris vulpes, are pathogenic for humans and can cause trichuriasis (Beer 1976; Kenney \& Yermakov 1980; Márquez-Navarro et al. 2012). The eggs of the first two species are very similar and cannot be distinguished by morphological or morphometric characteristics (Beer 1976; Soulsby 1982). Trichuris vulpes eggs are relatively larger than the range of normal variability, whereas Trichuris trichiura and Trichuris suis eggs are much smaller. Thus, the eggs that were found in individual 2 could belong to either of these two species. Evidence suggests that human trichuriasis caused by the helminth Trichuris suis is transient (Beer 1976). While we cannot completely exclude the possibility that the eggs belong to Trichuris suis, we believe that they do belong to Trichuris trichiura because that is the helminth most widespread among humans (Singh et al. 1993).

As previously explained, the unfavourable climatic conditions of a highland region with dry climate and low average annual precipitation, such as southern Siberia, would not allow Trichuris trichiura eggs to mature. So how did individual 2 contract this disease? In our opinion, two possibilities stand out. The first would involve the consumption of food contaminated with Trichuris trichiura eggs. Such foodstuffs could have been obtained through trade and might have included fruit, dried fruit or vegetables originating from areas with a warm and humid climate, such as the oases of Central Asia in western China, or from areas where human faeces were used as fertiliser, and where food was prepared with unwashed hands or in otherwise unsanitary conditions (Phuc et al. 2006; Ziegelbauer et al. 2012). Although the nomads of the Uyuk-saglynsk culture lived in a stratified society, both elites and non-elites, possibly including individual 2, would have had access to imported foodstuffs - a possible source of Trichuris trichiura eggs. Interestingly, despite the robbery of the grave in antiquity, a gold pectoral and a few gold ornaments were recovered from burial mound 6 (Chugunov 2007). The close link between early nomads from the Sayano-Altai region and the early states of Central Asia and China is supported by such archaeological finds as personal ornaments (bead necklaces, beads, cowrie shells, metal items), mirrors, spices (coriander), carpets and textiles (silk and felts of camel wool) (Rudenko 1953; Polosmak 2000; Molodin 2003).

It is also possible that individual 2 had visited areas in which trichuriasis was endemic. Sayano-Altai nomads are known to have engaged in raids that penetrated the territory of ancient China and the agricultural oases of ancient Central Asian states. Imported artefacts, fruits and seeds from these areas have been found at earlier archaeological sites (C) Antiquity Publications Ltd, 2018 
in Tuva. The richest burial mounds of the nomadic elite contain impressive artefacts that had undoubtedly been made specifically for the nomadic nobility by well-trained craftsmen resident in more densely settled areas. Such craftsmen may have also worked near burial grounds, at the behest of nomadic chiefs (Minasyan 2004; Chugunov 2011). Thus, inhabitants of the steppes may have migrated to distant southern countries, and natives of subtropical regions may have moved northwards, particularly for the purpose of trading.

All these scenarios involve the movement of goods if not people from south to north, suggesting that nomadic societies lived in close contact with the agricultural oases. This became the model for the so-called Silk Road, a long-distance trade route that was in constant use by various nomads. Southern Siberia in general and the Tuva Basin in particular were its northern branches (Rudenko 1953; Lubo-Lesnichenko 1988, 1994; Manning 2014). Such movements of people, goods and also parasites were clearly demonstrated in the analysis of hygienic sticks in the lavatory of trade caravans originating from Xuanquanzhi (dated 111 BC-AD 109) in the Taklamakan Desert in north-west China (Yeh et al. 2016). Apart from Ascaris lumbricoides and Taenia sp. eggs, researchers also found Clonorchis sinensis eggs, the modern and ancient endemic foci of which are located at least $1500 \mathrm{~km}$ away (Yeh et al. 2016), and Trichuris trichiura eggs. Trichuriasis could not have established itself in an arid climate such as that of the Taklamakan Desert, and the parasite probably penetrated Xuanquanzhi from Central Asia or China.

At Doge-Bary II we only found two examples of Trichuris trichiura eggs in one individual. To explain the absence of parasitic eggs in the mummified remains of individuals 3 and 4, we considered the process of artificial mummification to which these individuals had been subjected. The mummified bodies from Doge-Bary II were prepared in a similar manner to those found in the Pazyryk burial mounds 2 and 5, burial mound 1 at Ak-Alakha3 and burial mound 3 at Top-Kaldzhin II (Rudenko 1953; Polosmak 2000). It should be noted that the Pazyryk culture extended throughout the Altai Mountains, which are climatically similar to the Tuva Basin. The Pazyryk people dissected corpses as part of the mummification process. They removed all the internal organs and sometimes filled the abdominal, pelvic and thoracic cavities with soil, grass roots and stems, or, rarely, with wool. In some cases, to restore body volume, they used similar fillers after removing muscles and fat tissues. Finally, they closed the cavities using thread, tendons or horsehair sutures. The entire body was then embalmed with a substance that contained oil, beeswax and mercury. These activities were carried out to prolong the preservation of the body until the funeral (Molodin 2003). A similar procedure of intentional mummification practised by the Scythians was described by Herodotus:

Here, when the king dies, they dig a grave, which is square in shape, and of great size. When it is ready, they take the king's corpse, and, having opened the belly, and cleaned out the inside, fill the cavity with a preparation of chopped cypress, frankincense, parsleyseed, and anise-seed, after which they sew up the opening, enclose the body in wax, and, placing it on a wagon, carry it about through all the different tribes (Histories IV; 71; Rawlinson 1885; Polosmak 1996, 2000).

Removal of the intestines from the abdominal cavity was performed with care so as to maintain their integrity. The rectal ampulla cavity, which is located retroperitoneally 
(Zolotko 1967), was the only place opened during mummification. During removal of the bowel and rectum of individual 2, the soft tissues of the pelvis were probably contaminated with faeces, thus enabling us to detect the parasite eggs. Careful removal of the bowels could explain the absence of such parasitic eggs in the mummified remains of individuals 3 and 4 at Doge-Bary II.

\section{Conclusion}

This is the first direct evidence of parasitic disease among the Early Iron Age nomads of southern Siberia: Trichuris trichiura eggs were found in the mummified remains of individual 2 from Doge-Bary II (dating to the fifth and fourth centuries BC), a cemetery belonging to the Uyuk-saglynsk culture. From the evidence presented above, we might infer that the individual was infected with trichuriasis while visiting places where the helminth Trichuris trichiura was endemic, or while consuming imported food that could have originated in the oases of Central Asia or in China. This archaeoparasitological analysis confirms the existence of direct contact between the nomads of southern Siberia and distant agricultural areas, a relationship previously proposed only on the basis of circumstantial evidence. Further parasitological studies of archaeological Scythian-Siberian populations will provide additional new insights into nutrition, health and migration in ancient Siberia.

\section{Acknowledgements}

We would like to thank Piers Mitchell who greatly improved the quality of our article, and two anonymous reviewers for their comments on the earlier versions of this manuscript. Sergey Mikhailovich Slepchenko and Sergey Nikolaevich Ivanov are grateful for the support of the Russian Foundation for Basic Research (RFBR grant 17-06-00302 A). We also would like to thank T.A. Chikisheva, the Head of Anthropology, Sector of the Institute of Archaeology and Ethnography, Siberian Branch of the Russian Academy of Science (IAET SB RAS) for the opportunity to work with their collection of mummified materials from Doge-Bary II. Vyacheslav Sergeyevich Slavinsky and Alexander Alekseevich Tsybankov carried out this work within the research work plan of the IAET SB RAS (project 0329-2016-0007).

\section{References}

Araújo, A., K. Reinhard, O.M. Bastos, L.C. Costa, C. Pirmez, A. Iñiguez, A.C. Vicente, C.M. Morel \& L.F. Ferreira. 1998. Paleoparasitology: perspectives with new techniques. Revista do Instituto de Medicina Tropical de São Paulo 40: 371-76. https://doi.org/10.1590/S003646651998000600006

Ash, L.R. \& T.C. Orinel. 2007. Atlas of human parasitology. Chicago (IL): Pathology.

Aspöck, H., H. Auer \& O. Picher. 1996. Trichuris trichiura eggs in the Neolithic glacier mummy from the Alps. Parasitology Today 12: 255-56. https://doi.org/10.1016/0169-4758(96)30008-2

Aufderheide, A.C. 2003. The scientific study of mummies. Cambridge: Cambridge University Press.
BeER, R.J. 1976. The relationship between Trichuris trichiura (Linnaeus 1758) of man and Trichuris suis (Schrank 1788) of the pig. Research in Veterinary Science 20: 47-54.

Bianucci, R., E.J. Torres, J.M. Santiago, L.F. Ferreira, A.G. Nerlich, S.M. Souza, V. Giuffra, P.P. Chieffi, O.M. Bastos, R. Travassos \& W.D. Souza. 2015. Trichuris trichiura in a post-colonial Brazilian mummy. Memórias do Instituto Oswaldo Cruz 110(1): 145-47. https://doi.org/10.1590/0074-02760140367

Bundy, D.A.P., D.E. Thompson, H.M.N. Coolden, E.S. Cooper, R.M. Anderson \& P.S.E. Harland. 1985. Population distribution of Trichuris trichiura in a community of Jamaican children. Transactions of the Royal Society of Tropical Medicine and Hygiene 79: 232-37. https://doi.org/10.1016/0035-9203(85)90343-8

(C) Antiquity Publications Ltd, 2018 
Callen, E.O. \& T.W.M. Cameron. 1960. A prehistoric diet revealed in coprolites. New Scientist 7: 35-40.

Chugunov, K.V. 2007. Burial Doge-Bary II as a monument to Uyuk saglynsk culture formation of Tuva (based on excavations of 1990-1998), in S.V. Chavrin (ed.) Collection of scientific works in 295 honor of the $60^{\text {th }}$ anniversary of Vinogradov, A.V.: 123-45. Saint Petersburg: Cultural Information.

- 2011. Art Arjan-2: style, composition, iconography, ornamental motifs. European Sarmatia. Saint Petersburg: Nestor History (in Russian).

Cockburn, A., E. Cockburn \& T.A. Reyman. 1998. Mummies, disease and ancient cultures. Cambridge: Cambridge University Press. https://doi.org/10.1017/CBO9781139878340

Dufour, B. \& M. Le Bailly. 2013. Testing new parasite egg extraction methods in paleoparasitology and an attempt at quantification. International Journal of Paleopathology 3: 199-203. https://doi.org/10.1016/j.ijpp.2013.03.008

Fischer, C. 1980. Bog bodies of Denmark, in A. Cockburn \& E. Cockburn (ed.) Mummies, diseases and ancient cultures: 177-93. London: Cambridge University Press.

Fugassa, M.H., N.H. Sardella, R.A. Guichón, G.M. Denegri \& A. Araújo. 2008. Paleoparasitological analysis applied to museum-curated sacra from Meridional Patagonian collections. Journal of Archaeological Science 35: 1408-11. https://doi.org/10.1016/j.jas.2007.10.006

Gonçalves, M.L.C., A. Araújo \& L.F. Ferreira. 2003. Human intestinal parasites in the past: new findings and a review. Memórias do Instituto Oswaldo Cruz 98: 103-18. https://doi.org/10.1590/S007402762003000900016

Gvozdetsky, N.A. \& N. Mikhailov. 1978. Physical geography of the USSR. The Asian part. Moscow: Misl (in Russian).

Harter, S. 2003. Implication de la paléoparasitologie dans l'étude des populations anciennes de la vallée du Nil et de proche-orient: étude de cas.

Unpublished PhD dissertation, Université de Reims-Champagne Ardenne.

Kenney, M. \& V. Yermakov. 1980. Infection of man with Trichuris vulpis, the whipworm of dogs. American Journal of Tropical Medicine and Hygiene 29: 1205-1208. https://doi.org/10.4269/ajtmh.1980.29.1205

Kumm, K.J., K.J. Reinhard, D. Piombino-Mascali \& A. Araújo. 2010. Archaeoparasitological investigation of a mummy from Sicily $\left(18^{\text {th }}-19^{\text {th }}\right.$ century AD). L'Anthropologie 48: 177.
Letyagin, A.Y., A.A. Savelov \& N.V. Polosmak. 2014. High field magnetic resonance imaging of a mummy from Ak-Alakha-3 mound 1, Ukok Plateau, Gorny Altai: findings and interpretations. Archaeology, Ethnology \& Anthropology of Eurasia 60(4): 83-91 (in Russian).

https://doi.org/10.1016/j.aeae.2015.06.009

Lubo-LeSnichenko, E.I. 1988. Great Silk Road: east Turkestan in antiquity and the Early Middle Ages. Moscow: Nauka (in Russian).

- 1994. China on the Silk Road. Moscow: Nauka (in Russian)

Manning, J.G. 2014. At the limits: long-distance trade in the time of Alexander the Great and the Hellenistic kings, in V.H. Mair \& J. Hickman (ed.) Reconfiguring the Silk Road: new research on east-west exchange in antiquity: 5-14. Philadelphia: University of Pennsylvania Press.

Márquez-Navarro, A., G. García-Bracamontes, B.E. Álvarez-Fernández, L.P. Ávila-Caballero, I. Santos-Aranda, D.L. Díaz-Chiguer, R.M. SÁNChez-Manzano, E. Rodríguez-Bataz \& B. Nogueda-Torres. 2012. Trichuris vulpis (Froelich, 1789) infection in a child: a case report. Korean Journal of Parasitology 50: 69-71. https://doi.org/10.3347/kjp.2012.50.1.69

Minasyan, R.S. 2004. Secrets Scythian jewelers. Arjan: a source in the Valley of the Kings. Archeological discoveries in Tuva. Saint Petersburg: Slavia (in Russian).

Molodin, V.I. 2003. The population of the Altai Mountains in the Early Iron Age as an ethno-cultural phenomenon: origin, genesis, and historical destinies (from archeological, anthropological and genetic data). Novosibirsk: SB RAS (in Russian).

Nezamabadi, M., M. Mashkour, A. Aali, T. Stöllner \& M. Le Bailly. 2013. Identification of Taenia sp. in a natural human mummy (third century BC) from the Chehrabad salt mine in Iran. Journal of Parasitology 99: 570-72. https://doi.org/10.1645/12-113.1

Peck, W.H. 1998. Mummies of ancient Egypt, in A. Cockburn, E. Cockburn \& T. Reyman (ed.) Mummies, disease and ancient cultures: 15-37. Cambridge: Cambridge University Press. https://doi.org/10.1017/CBO9781139878340.005

Phuc, P.D., F. Konradsen, P.T. Phuong, P.D. Cam \& A. Dalsgaard. 2006. Practice of using human excreta as fertilizer and implications for health in Nghean Province, Vietnam. Southeast Asian Journal of Tropical Medicine and Public Health 37: 222-29.

Polosmak, N.V. 1996. The burial of a noble Pazyryk woman. Bulletin of Ancient History 4(219): 265-68 (in Russian).

- 2000. Mummification and embalming by the Pazyryk. The phenomenon of the Altai mummies. Novosibirsk: IAET SB RAS (in Russian).

(C) Antiquity Publications Ltd, 2018 
Rawlinson, G. 1885. The history of Herodotus. New York: Appleton and Company.

Reinhard, K. \& O. URban. 2003. Diagnosing ancient diphyllobothriasis from Chinchorro mummies. Memórias do Instituto Oswaldo Cruz 98: 191-93. https://doi.org/10.1590/S007402762003000900028

Reinhard, K.J., S.A. Mrozowski \& K.A. Orloski. 1986. Privies, pollen, parasites, and seeds, a biological nexus in historic archaeology. Masca Journal 4(1): 31-36.

Rudenko, S.I. 1953. The culture of the population of the Altai Mountains in Scythian times. Moscow \& Leningrad: USSR Academy of Sciences.

Searcey, N., K.J. Reinhard, E. Egarter-Vigl, F. Maixner, D. Piombino-Mascali, A.R. ZinK, W. der Sanden, S.L. Gardner \& R. Bianucci. 2013. Parasitism of the Zweeloo Woman: dicrocoeliasis evidenced in a Roman-period bog mummy. International Journal of Paleopathology 3: 224-28. https://doi.org/10.1016/j.ijpp.2013.05.006

Sianto, L., K.J. Reinhard, M. Chame, S. Chaves, S. Mendonça, M.L. Gonçalves, A. Fernandes, L.F. Ferreira \& A. Araújo. 2005. The finding of Echinostoma (Trematoda: Digenea) and hookworm eggs in coprolites collected from a Brazilian mummified body dated 600-1,200 years before present. Journal of Parasitology 91: 972-75. https://doi.org/10.1645/GE-3445RN.1

Singh, S., J.C. Samantaray, N. Singh, G.B. Das \& I.C. Verma. 1993. Trichuris vulpis infection in an Indian tribal population. Journal of Parasitology 79: 457-58. https://doi.org/10.2307/3283589

Slepchenko, S.M., S.N. Ivanov, A.N. Bagashev, A.A. Tsybankov \& V.S. Slavinsky. 2016. Traditional living habits of the Taz Tundra population: a paleoparasitological study. Korean Journal of Parasitology 54: 617-23. https://doi.org/10.3347/kjp.2016.54.5.617
Slepchenko, S.M., S.N. Ivanov, A.V. Vybornov, T.A. Alekseevich, S.V. Sergeyevich, D.N. Lysenko \& V.E. Matveev. 2017. Taenia sp. in human burial from Kan River, east Siberia. Memórias do Instituto Oswaldo Cruz 112: 387-90. https://doi.org/10.1590/0074-02760160442

Soulsby, E.J.L. (ed.). 1982. Helminths, arthropods and protozoa of domesticated animals. London: Bailliere, Tindall \& Cassell.

Vozianova, J.S. 2000. Infectious and parasitic diseases. Kiev: Health Protection (in Russian).

WEI, O. 1973. Internal organs of a 2100-year-old female corpse. The Lancet 7839: 1198. https://doi.org/10.1016/S0140-6736(73)92953-X

YANG, W., G. Song \& R. Teng. 1984. Parasitologische Untersuchung einer alten Leiche aus der Chu-Dynastie der Streitenden Reiche aus dem Mazhuan-Grab Nr. 1, Kreis Jiangling, Provinz Hubei. Acta Academiae Medicinae Wuhan 4: 23-27.

YeH, H.-Y. \& P.D. Mitchell. 2016. Ancient human parasites in ethnic Chinese populations. Korean Journal of Parasitology 54: 565-72. https://doi.org/10.3347/kjp.2016.54.5.565

Yeh, H.-Y., R. Mao, W. Hui, W. Qi \& P.D. Mitchell. 2016. Early evidence for travel with infectious diseases along the Silk Road: intestinal parasites from 2000-year-old personal hygiene sticks in a latrine at Xuanquanzhi Relay Station in China. Journal of Archaeological Science: Reports: 758-64.

Ziegelbauer, K., B. Speich, D. Mäusezahl, R. Bos, J. Keiser \& J. Utzinger. 2012. Effect of sanitation on soil-transmitted helminth infection: systematic review and meta-analysis. PLoS Medicine 9: e1001162. https://doi.org/10.1371/journal.pmed.1001162

Zоцотко, Ju.L. 1967. Atlas of topographical anatomy of man. Moscow: Medicine (in Russian).

Zubova, A.V. 2009. On the question of mummification in the early Scythian population of Tuva. Problems of Archeology, Ethnography, Anthropology: Siberia and Adjacent Territories 15: 267-69 (in Russian).

Received: 17 January 2017; Accepted: 15 June 2017; Revised: 4 September 2017

(C) Antiquity Publications Ltd, 2018 